Available online on 15.03.2020 at http://jddtonline.info
Open Access to Pharmaceutical and Medical Research
unrestricted non-commercial use, provided the original work is properly cited

Open Access

Case Report

\title{
A Case Report of Nephrotic Syndrome with Anasarca in 3-Year-Old Girl
}

\author{
Md Nematullah ${ }^{* 1}$, Keshav Sharma ${ }^{1}$, Rajveer Singh ${ }^{1}$, Ranjeet Kumar ${ }^{1}$ \\ ${ }^{1}$ Department of Pharmacy Practice, NIMS Institute of Pharmacy, NIMS University Rajasthan, Jaipur, India
}

\begin{abstract}
Nephrotic syndrome (NS) is the most commonly encountered glomerular diseases in the child. One of the major problems in this disorder is hyper coagulopathy and increased risk of thrombosis. The cause of thrombosis is related to an imbalance of coagulation and anticoagulation factors. A 3-year-old female patient admitted in the pediatric ward with chief complaints is swelling over the face, hand, and legs from 10-12 days and mild pain in the abdomen 2-3 episode. While there are several more common causes of abdominal pain in children with nephrotic syndrome. This study reports that swelling over the face, hand, and legs. If Patients can take proper medication they can decrease the edema and improve their condition.
\end{abstract}

Keywords: Nephrotic syndrome, Anasarca, Edema

Article Info: Received 04 Jan 2020; Review Completed 19 Feb 2020; $\quad$ Accepted 26 Feb 2020; Available online 15 March 2020

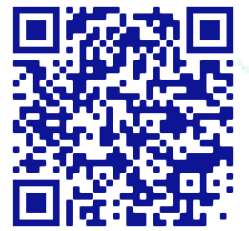

\section{Cite this article as:}

Nematullah M, Sharma K, Singh R, Kumar R, A Case Report of Nephrotic Syndrome with Anasarca in 3-Year-Old Girl, Journal of Drug Delivery and Therapeutics. 2020; 10(2):206-207 http://dx.doi.org/10.22270/jddt.v10i2.3986

*Address for Correspondence:

Md Nematullah, Department of Pharmacy Practice, NIMS Institute of Pharmacy, NIMS University Rajasthan, Jaipur, India

\section{INTRODUCTION}

Nephrotic syndrome (NS) is the most commonly encountered glomerular diseases in the child and a major contributor to the workload of pediatric nephrologists1. One of the major problems in NS is hyper coagulopathy and increased risk of thrombosis. The main cause of thrombosis is the imbalance of coagulation and anticoagulation factors. The risk is increased by thrombocytosis, hemoconcentration, hyperviscosity, a decrease of physical activity, use of corticosteroids and diuretic ${ }^{2}$. Heavy proteinuria, clinically manifesting as the nephrotic syndrome, is almost always due to primary renal involvement in childhood ${ }^{3}$. The majority of children and adults respond to initial of treatment with glucocorticoids by entering into clinical remission, a substantial proportion of the patients $(\sim 15 \%$ of children and $55 \%$ of adults) either present with or subsequently develop clinical steroid resistance during their disease 4 . Diagnosis is generally based on clinical features and investigations including blood tests, renal imaging, and biopsy 5 .

\section{CASE REPORT}

A 3-year-old female patient admitted in the pediatric ward with chief complaints is swelling over the face, hand, and legs from 10-12 days and mild pain in the abdomen 2-3 episode. History of present illness is she was alright 10 days back when she develops edema first on the face than hand, legs and whole body and also a history of a distended abdomen.
Past medication history of pain in ear relieved by medication. Laboratory investigation of biochemistry analysis ( serum creatinine $(0.40 \mathrm{mg} / \mathrm{dl})$, serum cholesterol $(411.0 \mathrm{mg} / \mathrm{dl})$, total protein $(4.2 \mathrm{~g} / \mathrm{dl})$, albumin $(1.90 \mathrm{~g} / \mathrm{dl}), \mathrm{A} / \mathrm{G}$ ratio $(0.82)$, triglycerides $(520.0 \mathrm{mg} / \mathrm{dl})$, HDL cholesterol $(67.0 \mathrm{mg} / \mathrm{dl})$, LDL cholesterol $(240.0 \mathrm{mg} / \mathrm{dl})$ and VLDL cholesterol $(104.0$ $\mathrm{mg} / \mathrm{dl})$. Other blood investigations are ESR (34 1st $\mathrm{hr} \mathrm{mm})$, neutrophils (62\%), lymphocyte $(32 \%)$, MCHC (34.6 g/dl) and platelet count $\left(476 \times 10^{\wedge} 3 / \mathrm{uL}\right)$. Based on medical history, clinical examination our diagnosis was Anasarca with nephrotic syndrome.

The patient was treated under the expert guidance of a pediatrician with antibiotic Injection Ceftriaxone $500 \mathrm{mg}$ in Normal saline twice a day for 4 days. Diuretic Injection Furosemide $1.5 \mathrm{ml}(10 \mathrm{mg} / \mathrm{ml})$ in Normal saline twice a day 2 days then further change to oral furosemide +Spironolactone for 2 days. Tab Prednisolone 20mg at $8 \mathrm{am} \& 5 \mathrm{mg}$ at $8 \mathrm{pm}$ for six weeks. Treatment is based on patient age, body weight, and severity. Follow up after 6 weeks of therapy.

\section{DISCUSSION}

The rate of incidence of nephrotic syndrome in children worldwide is 2-7 per 100,000 children. Nephrotic syndrome is a kidney disorder that causes your body to pass too much protein in the urine. Nephrotic syndrome is caused by damage to the clusters of small blood vessels in the kidneys that filter waste products and the excessive water from the blood. In that condition causes swelling, particularly in feet 
and ankles, and increases the risk of other health problems. Treatment for nephrotic syndrome and anasarca includes treating the condition that's causing it and taking medications. The risk of infections and blood clots is increases in nephrotic syndrome. In this case severe swelling (edema), around on eye, ankles, feet and whole body.

The patient was a 3 years old female who came to the hospital with chief complaints of swelling over the face, hand, legs and mild pain in the abdomen. A patient will receive care from a team of health professionals, including physicians, clinical pharmacists, and nursing staff. After getting proper care from the pediatrician her condition was better and swelling decreases. A patient has to take medication properly as prescribed by the pediatrician. And follow up for the next therapy after 6 weeks. Her parents were counseled properly to take care of his child and do suggested medication routinely for more improvement.

\section{CONCLUSION}

While there are several more common causes of abdominal pain in children with nephrotic syndrome. Our study reports that swelling over the face, hand, and legs will decrease after proper medication. Therefore, the parents must aware of medication for this child and help them to improve in their condition.

\section{ACKNOWLEDGMENT}

I take this opportunity to thank my parents, all the faculty members for their help and support to publish this case report.

\section{CONFLICT OF INTEREST: None. \\ REFERENCES}

1. Louansha Nandlal, Thajasvarie Naicker, and Rajendra Bhimma. Nephrotic Syndrome in South African Children: Changing Perspectives in the New Millennium: Kidney International Reports 2019; 4, 522-534.

2. Ali Nikkhah, Roghayeh Akbari, Hadi Sorkhi. A case report of nephrotic syndrome with hemorrhage of intracerebral in cerebral venous thrombosis: Caspian Journal of Pediatrics, Sep 2015; 1( 2): 73-76.

3. R. N. Srivastava, G. Mayekar, R. Anand, V. P. Choudhry, et al., Nephrotic syndrome in Indian children: Archives of Disease in Childhood 1975; 50, 626-30.

4. Shipra Agrawal, Joshua J. Zaritsky, Alessia Fornoni, William E. Smoyer. Dyslipidaemia in nephrotic syndrome: Mechanisms and Treatment: Nat Rev Nephrol 2018; 14(1): 57-70.

5. Phanekham Souvannamethy. Management of Nephrotic Syndrome: A Case Report from Lao PDR: Blood Purification 2017; 44(1): 31-34. 